\title{
Model Pengembangan Manajemen Sumber Daya Manusia UMKM Sektor Makanan dan Minuman di Era Covid-19
}

\author{
Cakti Indra Gunawan ${ }^{1}$, Siti Qodriyatus Solikhah ${ }^{2}$, and Yulita ${ }^{3}$ \\ ${ }^{1}$ Universitas Tribhuwana Tunggadewi Malang \\ Program Studi Manajemen \\ Jl. Tlogo Warna, Malang 65144, Indonesia \\ E-mail: cakti.gunawan@gmail.com \\ ${ }^{2}$ Politeknik Kesehatan Kemenkes Malang \\ Program Studi Sarjana Terapan Gizi dan Dietetika \\ Jl. Besar Ijen No. 77 Malang \\ E-mail: ikaqdry2@gmail.com \\ ${ }^{3}$ Universitas Widya Dharma Pontianak \\ Program Studi Akuntansi \\ Jl. Tabrani Ahmad Kompleks Kencana Lestari Blok C No. C12, Pontianak 78115 \\ E-mail: yulitaputrikumpot@gmail.com
}

\begin{abstract}
Abstrak
Usaha Mikro Kecil dan Menengah (UMKM) di Indonesia mengalami penurunan pendapatan selama pandemi COVID-19. Salah satu pendorong UMKM adalah sumber daya manusia yang selama pandemi perlu ditingkatkan sebagai bentuk optimalisasi UMKM. Tujuan penelitian ini adalah menjelaskan bagaimana model pengembangan manajemen sumber daya manusia diimplementasi sebagai optimalisasi UMKM selama pandemic. Metode yang digunakan adalah literature review bersumber data sekunder dan kajian penelitian terdahulu. Penelitian ini akan memberikan kontribusi keilmuan permodelan manajemen sumber daya manusia pengelolaan UMKM di saat pandemi. Hasil penelitian menunjukkan bahwa pemanfaatan teknologi dan informasi signifikan berpengaruh dalam peningkatan kinerja dan skill pelaku usaha. Kesimpulan penelitian ini menunjukkan bahwa teknologi dan informasi dapat mengoptimalisasi pengembangan sumber daya manusia UMKM selama pandemi COVID-19.
\end{abstract}

Kata Kunci: Manajemen Sumberdaya Manuusia, UMKM, Makanan dan Minuman, COVID-19

\begin{abstract}
Micro, Small and Medium Enterprises (MSMEs) in Indonesia experienced a decline in income during the COVID-19 pandemic. One of the drivers of MSMEs is human resources, which during the pandemic needs to be improved as a form of optimizing MSMEs. The purpose of this study is to explain how the human resource management development model is implemented as an optimization of MSMEs during the pandemic. The method used is a literature review sourced from secondary data and previous research studies. This research will contribute to the scientific contribution of human resource management modeling for the management of MSMEs during a pandemic. The results of the study indicate that the use of technology and information has a significant effect on improving the performance and skills of business actors. The conclusion of this study shows that technology and information can optimize the development of MSME human resources during the COVID-19 pandemic.
\end{abstract}

Keywords: Human Resources Management, MSME, Food and Beverage, COVID-19.

\section{Pendahuluan}

Usaha Mikro Kecil dan Menengah (UMKM) adalah penunjang ekonomi nasional dan daerah (Lubis, 2016; Febriayntoro, 2018; Fauji, 2019). UMKM menjadi salah satu sektor usaha yang diunggulkan untuk mendorong pertumbuhan ekonomi. Dalam pengembangannya, perlu adanya upgrade dari berbagai aspek yang menjadi fondasi pelaksanaan usaha, salah satunya adalah sumber daya manusia. 
Aktivitas UMKM Indonesia tersebar di seluruh provinsi, salah satu provinsi yang memiliki aktivitas ekonomi UMKM secara signifikan dan menjadi focus penelitian ini adalah Jawa Timur. Aktivitas ekonomi di Jawa Timur mendominasi dengan proporsi dengan angka sebesar $98.95 \%$ (BPS, 2018). Akan tetapi, saat pandemi COVID-19, UMKM di Jawa Timur mengalami penurunan aktivitas ditandai dengan penurunan penjualan dan pendapatan bisnis sebesar 98.35\% (Rodriguez, 2017).

Strategi penjualan diperlukan sebagai bentuk pertahanan dan eksistensi usaha saat pandemi COVID-19. Salah satu cara adalah dengan memilih strategi yang adaptable dengan kemampuan dan kondisi suatu wilayah berdasarkan karakteristik masing-masing. Hal ini akan mendorong pelaksanaan pengembangan aspek yang menjadi fondasi UMKM, salah satunya adalah sumber daya manusia. Sumber daya manusia menjadi aspek yang penting sebagai pelaku utama dalam pelaksanaan proses bisnis UMKM.

Pengembangan sumber daya manusia dapat berfokus pada peningkatan skill dan kinerja pegawai untuk mencapai hasil yang optimal dan efektif dalam proses aktivitas usaha. Peningkatan skill SDM UMKM penting dilakukan dipelopori oleh signifikansi pengurangan karyawan atau Pemutusan Hubungan Karyawan (PHK) pada beberapa perusahan mikro, kecil, dan menengah yang memengaruhi proses pelaksanaan bisnis. Maka dari itu, perlu adanya solusi dalam memberdayakan sumber daya manusia sektor UMKM secara efektif dan optimal.

Peningkatan skill SDM UMKM dapat melalui kegiatan pelatihan dan pendidikan, secara offline atau online. Beberapa penelitian telah mengkaji bagaimana implementasi pelatihan sebagai kegiatan pengembangan sumber daya manusia dapat meningkatkan kemampuan dalam mengolah bisnis (Setyorini, 2019; Cahya, 2021; Andayani, 2021). Namun, penelitian di atas belum fokus membahas mengenai pelatihan berbasis teknologi dan informasi.

Aktivitas pelaku bisnis mengalami perbedaan penerapan dibandingkan dengan sebelum dan saat pandemi COVID-19. Sebelum pandemi, pelaku bisnis masih melakukan pengoptimalan sumber daya manusia dalam memasarkan produk UMKM dengan metode tradisional (Ling, 2013; Alford, 2015). Saat pandemi, inovasi terus diusahakan untuk menunjang aktivitas UMKM, salah satunya dengan mengoptimalkan model baru strategi pemasaran menggunakan teknologi dan informasi.

Penelitian sebelumnya juga mengutarakan bahwa pelaku usaha masih belum menerapkan teknologi informasi secaea optimal (Hendriadi, 2019). Dijelaskan bahwa bisnis yang menerapkan sistem lama akan memiliki potensi untuk tertinggal dengan pesaing bisnis yang menerapkan sistem terbaru (Bin, 2020). Digital marketing memudahkan pelaku UMKM untuk memberikan informasi dan berinteraksi secara langsung dengan konsumen, memperluas pangsa pasar, meningkatkan awareness dan meningkatkan penjualan bagi pelaku UMKM (Fauji, 2019).

Beberapa penelitian terdahulu telah menjelaskan bagaimana inovasi sebagai model pengembangan untuk meningkatkan kinerja dan produksi UMKM, namun masih terdapat kekurangan dalam pembahasan tentang bagaimana implementasi pada saat pandemi COVID-19. Untuk memenuhi kekurangan dalam keilmuan sumber daya manusia, maka penelitian ini berorientasi sebagai kajian lebih dalam mengenai model pengembangan sumber daya manusia UMKM selama pandemi COVID-19.

\section{Tinjauan Pustaka}

Manajemen sumber daya manusia sebagai salah satu elemen penting dalam pengelolaan Usaha Mikro Kecil dan Menengah, telah mengalami pasang surut pandangan dan inovasi keilmuan. Salah satu pandangan keilmuan yang terbaru di saat pandemi COVID-19 adalah integrated system berbasiskan teknologi informasi yang dapat diakses oleh pembeli dan penjual menjadi salah satu penguat pengembangan keilmuan manjemen sumber daya di saat pandemi COVID-19 (Gunawan, 2016).

Usaha Mikro Kecil Menengah (UMKM) merupakan perusahaan yang berskala mikro, kecil dan menengah. Usaha mikro merupakan usaha yang produtif milik orang perorangan dan atau badan usaha perorangan yang memenuhi kriteria sebagaimana diatur dalam undang-undang ini (Anggareni, 2015). Inovasi dalam berbisnis sangat penting dilaksanakan di tengah pandemi yang terjadi saat ini untuk meningkatkan pertumbuhan dan performa perusahaan (Hartono, 2018).

Selama masa pandemi COVID-19, terjadi perubahan perilaku sumber daya manusia yang berdampak pada hasil kegiatan. Fenomena ini menyebabkan kurangnya sumber daya manusia yang optimal dalam hal administrasi modern dan manual. Selama masa krisis pangan akan terjadi pergeseran perilaku makroekonomi dan pengelolaan sumber daya manusia dalam pengelolaan negara. Perlu penanganan lebih lanjut untuk menjaga kinerja SDM sebagai pendukung program (Gunawan, 2015). Maka dari itu, mengoptimalkan pengelolaan sumber daya manusia diperlukan dari pendampingan pemerintah daerah untuk mencapai hasil yang optimal.

Salah satu usaha dalam peningkatan skill pelaku usaha UMKM adalah dengan cara melaksanakan kursus atau training secara online seperti yang dikaji pada beberapa penelitian sebelumnya menunjukkan bahwa 
pelatihan signifikan dalam peningkatan kinerja dan proses kerja UMKM dalam menjalankan bisnis dalam sektor makanan dan minuman (Hakim, 2019; Yuwinanto, 2020; Harel, 2021).

\section{Metode Penelitian}

Penelitian ini menggunakan metode kajian literatur berdasarkan sumber data sekunder dengan pencarian jurnal menggunakan database berbasis web Google Scholar dan Repository yang menelaah kajian berdasarkan kata kunci. Metode literature review adalah sebuah metode yang mengkomparasikan dan memotret sebuah kajian dari sudut pandang literatur yang ada di buku maupun dijurnal serta literatur lainnya seperti hasil komperensi dan surat kabar (Creswell, 2017).

Adapun penelitian ini tidak memfokuskan pada populasi dan sampel UMKM, namun lebih kepada solusi permodelan sumber daya manusia yang berbasiskan teknologi dan informasi. Penelitian ini merupakan hasil implikasi dari fenomena yang telah terjadi di masyarakat, data ditunjukkan oleh laporan yang disajikan berdasarkan sumber literatur (Khairunnisa, 2020).

\section{Hasil dan Pembahasan}

\section{Dampak Pandemi COVID-19 Terhadap UMKM Sektor Makanan dan Minuman}

Masa krisis ekonomi akibat pandemi berdampak pada berbagai sektor UMKM, salah satunya pada sektor makana dan minuman. Ditunjukkan oleh Laporan Ketahanan UMKM Jawa Timur saat Pandemi COVID-19 bahwa sebanyak 1.785 koperasi dan 163.713 pelaku usaha mikro kecil menengah terdampak pandemi virus corona (COVID-19). Mayoritas sektor yang terdampak COVID-19 bergerak pada bidang kebutuhan sehari-hari, sedangkan sektor UMKM yang paling terdampak yakni makanan dan minuman (Soetjipto, 2020).

Pendapatan UMKM saat pandemi rerata mengalami penurunan ditunjukkan pada grafik di bawah ini

\section{Tingkat penurunan pendapatan (\%)}

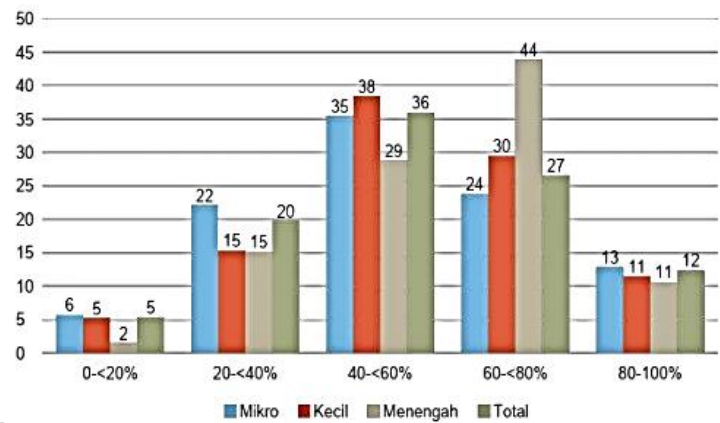

\section{Gambar 1: Tingkat Penurunan Pendapatan (\%)}

Sumber: Bappenas, 2020. Kajian Kebijakan Penanggulangan Dampak COVID-19 terhadap UMKM Survei Kebutuhan Pemulihan Usaha Bagi UMKM Indonesia.

Pendapatan UMKM berdasarkan skala di Indonesia rerata sebanyak $98.35 \%$ mayoritas mengalami penurunan, diikuti sebanyak $0.825 \%$ pendapatan bertambah, dan sisanya sebanyak $0.825 \%$ tidak terdapat perubahan. Faktor yang mendukung aktivitas UMKM salah satunya ditunjang oleh sumber daya manusia yang optimal. Selama pandemi COVID-19, terjadi pengurangan karyawan yang menyebabkan kinerja sumber daya manusia mengalami penurunan.

Menurunnya sumber daya manusia UMKM, terutama pada sektor makanan dan minuman berdampak pada proses produksi dan aktivitas UMKM yang menyebabkan harus behenti berproses (Mandasari, 2019). Untuk meningkatkan profit secara signifikan perlu adanya rencana strategis perusahaan, serta kapabilitas karyawan (Lazear, 2018).. Berdasarkan hal ini maka faktor sumber daya manusia perlu dioptimalkan supaya memiliki kinerja yang adaptable saat pandemi COVID-19.

Pelaku bisnis UMKM selama pandemi COVID-19 berusaha mengembangkan strategi baru menyesuaikan dengan pergeseran perilaku masyarakat. Salah satu strategi yang dikembangkan adalah pemasaran, ditunjukkan pada gambar di bawah ini

Gambar 2: Strategi pemasaran UMKM Sektor Makanan dan

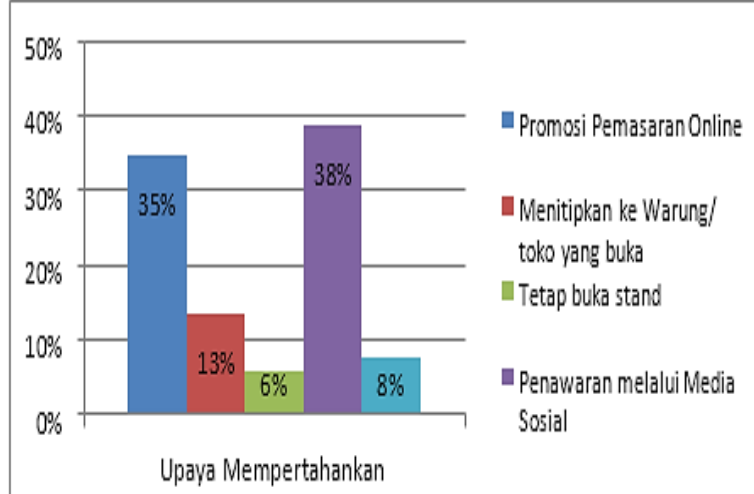

Minuman Saat Pandemi COVID-19

Sumber: Soetjipto, 2020. Ketahanan UMKM Jawa Timur Melintasi Pandemi COVID-19.

Pada gambar 2 diketahui sebanyak $38 \%$ para pelaku usaha melakukan pemasaran atau menawarkan dagangannya melalui media sosial, dan $35 \%$ para pelaku usaha menggunakan media online sebagai alat pemasaran, yaitu promosi berbayar yang tersedia online. Namun terdapat $13 \%$ pelaku usaha yang masih bertahan dengan cara konvensional yaitu menitipkan produk dagangannya ke toko-toko atau warung yang masih buka, ini dilakukan oleh peaku usaha home 
industri makanan kemasan.

Mendukung pengembangan strategi pemasaran menggunakan teknologi dan infromasi yang dilakukan oleh pelaku bisnis, maka dibutuhkan technical support sebagai pendorong pelaksanaan, antara lain sumber daya manusia dan alat pendukung. Sumber daya manusia yang kompeten dan alat yang mendukung dapat mengoptimalkan output pendapatan UMKM. Maka dari itu, peneliti mencoba mengembangkan model terbaru dalam pendorong sumber daya manusia pada aktivitas UMKM yang diharapkan dapat menjadi sebuah inovasi untuk mendorong produktivitas UMKM selama pandemi COVID-19.

Model Pengembangan Manajemen Sumber Daya Manusia UMKM Sektor Makanan dan Minuman di Era COVID-19

Pengembangan model manajemen sumber daya manusia telah dikembangkan oleh beberapa penelitian terdahulu. Pada penelitian terdahulu telah dirancang manajemen sumber daya manusia yang dinamakan Gemba Kaizen (Hardilawati, 2019), manajemen ini berfokus pada kualitas dan pengolahan data yang akurat. Selain itu, model lain yang telah dikembangkan penelitian terdahulu adalah model manajemen pengembangan sumber daya manusia yang berbasis komunikasi, nilai, dan komunikasi multi budaya yang berfokus pada peningkatan kualitas interaksi antar budaya melalui komunikasi yang baik (Sumampouw, 2021).

Saat ini, UMKM berusaha meningkatkan kinerja pelaku usaha salah satunya dengan cara mengikuti pelatihan yang bertujuan dalam peningkatan skill. Data yang didapatkan dari, pelaku usaha masih menerapkan sebuah pelatihan yang dilakukan dengan metode tradisional. Seperti kegiatan yang diadakan oleh Pemerintah Provinsi Jawa Timur, implementasi kegiatan masih belum memanfaatkan teknologi secara optimal dalam penyelenggaraan pelatihan UMKM (Mukhsin, 2019). Mayoritas UMKM mengikuti kegiatan pelatihan secara offline atau tatap muka. Implementasi kegiatan pelatihan secara offline perlu upgrading untuk menyesuaikan kondisi pandemi yang membatasi pertemuan. Salah satunya dengan memanfaatkan teknologi dan informasi berbasis online untuk berkomunikasi dengan peserta (Marchand, 2021).

Beberapa penelitian terdahulu telah berkontribusi dalam pengelolaan manajemen sumber daya manusia, baik secara internal maupun eksternal. Namun, belum terdapat permodelan sumber daya manusia yang berfokus pada pengembangan UMKM, terutama pada sektor makanan dan minuman. Berikut adalah contoh model pengembagan yang berfokus pada optimalisasi kinerja dan skill sumber daya manusia pengelola
UMKM pada sektor makanan dan minuman. Sebagai berikut

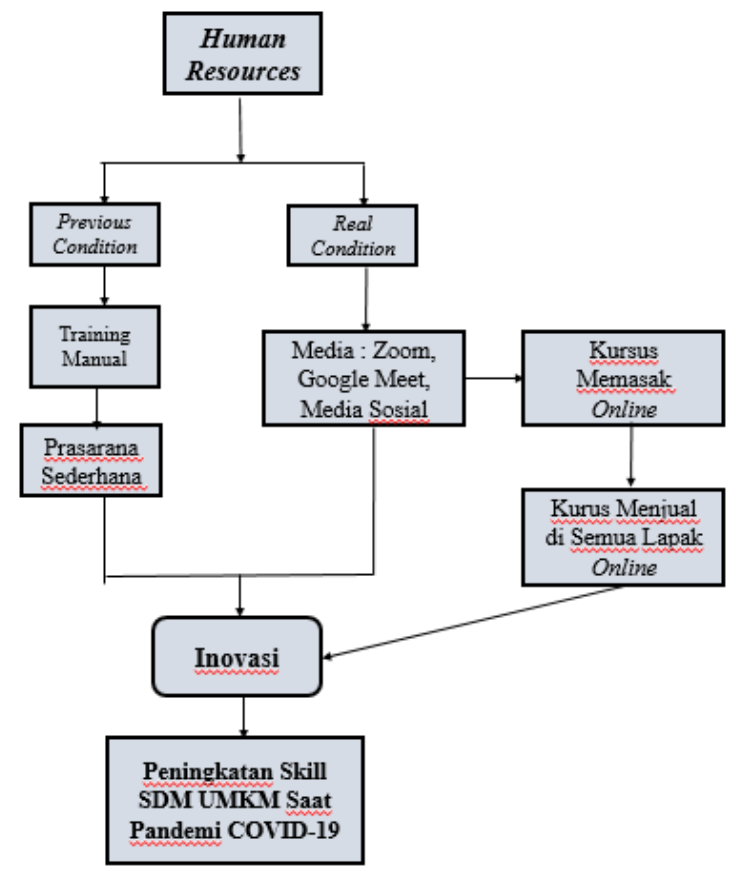

Gambar 3: Model Pengembangan Manajemen SDM UMKM Sektor Makanan dan Minuman Saat Pandemi COVID-19

Sumber: Penulis

Sebagai dukungan inovasi pengembangan UMKM saat pandemi COVID-19, terutama pada sektor makanan dan minuman yang krusial, maka optimalisasi sumber daya manusia dapat dilakukan dengan cara kursus secara online atau dalam jaringan. Hal ini dinilai dapat menjadi salah satu inovasi yang menititikberatkan pada transformasi digital yang berbeda dengan sebelum pandemi. Sebelum pandemi, kursus, pelatihan, dan peningkatan skill dilakukan secara offline, namun saat pandemic berinovasi menjadi pelatihan berbasiskan online.

Penerapan pelatihan kepada karyawan telah diimplementasi salah satunya di negara Timur Tengah yang menunjukkan bahwa cara meningkatkan skill dan kinerja karyawan di suatu perusahaan adalah dengan pengadaan kursus sesuai dengan bidang pengkajian masing-masing (Gunawan, 2020; Angdika, 2019). Hal ini dilakukan supaya sumber daya manusia perlu dikembangkan dapat berkembang secara optimal dan efisien sebagai pendukung dalam pelaksanaan suatu proses bisnis.

Pemberdayaan UMKM dalam arus globalisasi dan persaingan yang tinggi membuat UMKM harus mampu menghadapi tantangan global, terutama saat pandemi COVID-19 yang membutuhkan peningkatan inovasi produk dan layanan, pengembangan sumber daya manusia dan teknologi, serta perluasan wilayah pemasaran (Ludiya, 2017). Manfaat pelatihan Upaya pengembangan sumberr daya manusia memiliki tujuan 
untuk meningkatkan manajemen kinerja pelaksanaan usaha yang bermanfaat untuk dalam mengolah usahanya secara internal atau eksternal secara optimal

Pengembangan sumber daya manusia sebagai pelaksana UMKM dapat diimplementasikan melalui manajemen usaha. Manajemen pengembangan sumber daya manusia perlu terus dilakukan sebagai bentuk inovasi dan ketahanan UMKM supaya tetap beroperasi selama pandemi. Kegiatan ini penting dilakukan saat kondisi krisis karena pemulihan suatu perusahaan perlu kemampuan yang dinamis dan inovatif untuk mempercepat melewati kondis krisis dengan cepat (Ekasari, 2018).

Kebaharuan dalam peningkatan skill pelaku usaha dapat dilihat dari pelaksanaan kursus online yang dipandu oleh pemerintah. Melalui program dana peningkatan ekonomi UMKM saat pandemi COVID-19 yang diterapkan oleh Dinas Koperasi dan UMKM Kota Malang selama satu tahun ini. Diharapkan dengan model ini akan mempermudah pihak pemerintah dan UMKM untuk sama-sama mengembangkan kualitas sumber daya manusia. Implementasi dari model pengembangan manajemen sumber daya manusia dalam peningkatan skill pelaku usaha yang dikembangkan oleh penulis berfokus pada tiga step yang krusial.

Hal pertama yang disiapkan adalah instrumen yang terdiri dari buku panduan atau modul yang menjelaskan bagaimana cara pemasaran hasil UMKM dengan berbasiskan teknologi dan informasi yang dikeluarkan oleh Dinas Koperasi dan UMKM Kota Malang. Selanjutnya menyediakan pelatih/trainer sebagai pembimbing dalam penyelenggaraan kursus yang berasal dari perguruan tinggi yang atau praktisi yang ditunjuk oleh Dinas Koperasi untuk melatih dan memandu pelaku usaha UMKM di sektor makanan dan minuman dengan jadwal yang terstruktur. Selein itu, diperlukan penyusunan kurikulum yang berbasis bagaimana cara peningkatan kemampuan pelaku usaha UMKM menggunakan teknologi dan informasi, kurikulum ini akan ditinjau oleh para ahli dan praktisi yang ditunjuk oleh pemerintah.

Proses implementasi kursus online ini akan dilaksanakan dengan urutan kegiatan yang dimulai dengan pengumpulan para pengusaha UMKM di Dinas Koperasi dan UMKM Kota Malang secara periodik. Selanjutnya, para pengusaha UMKM sektor makanan dan minuman mendaftarkan diri ke Dinas Koperasi dan UMKM yang akan dilatih selama 120 jam dengan hasil akhir uji kompetensi mampu menjual makanan dan minuman di lapak online. Pemerintah terus melatih dan mendampingi selama proses penggunaan teknologi dengan membuatkan platform diskusi seperti whatsapp group dan lapak online yang berisikan UMKM sektor makanan dan minuman di Kota Malang.

Diharapkan outcome yang didapatkan dari implementasi kegiatan ini adalah peningkatan skill dalam menjual produk di platform yang berbasisikan online dan pelaku usaha lebih mahir dalam mengoperasikan teknologi dan informasi. Hal ini dapat berkontribusi dalam peningkatan kinerja sumber daya manusia pengelola UMKM. Yang berpotensi dalam peningkatan pendapatan UMKM selama pandemi.

Pemberdayaan sumber daya manusia berbasis online telah dikaji dalam beberapa penelitian. Hasil penelitian menunjukkan bahwa pelatihan dan pendidikan pegawai dengan pemanfaatan teknologi dan infromasi signifikan meningkatkan kinerja pegawai. Berikut adalah hasil implementasi teknologi informasi yang memengaruhi peningkatan pendapatan, antara lain sebagai berikut



Gambar 4: Dampak Strategi Digital Marketing Terhadap Peningkatan Potensi Sumber Daya Manusia Pengelola UMKM

Sumber: Peran Pemerintah Daerah dalam Mengembangkan UMKM yang Terdampak COVID-19. Islami, 2021.

Pemanfaatan sarana digital marketing membawa dampak pada kinerja dan skill sumber daya manusia yang berpotensi dalam aspek penjualan UMKM, salah satunya terdapat peningkatan omzet dan pendapatan perusahaan. $75.4 \%$ pelaku UMKM mendapatkan manfaat peningkatan pendapatan bahkan $26.2 \%$ pendapatannya meningkat lebih dari $30 \%$. Hal ini sesuai dengan temuan yang menyimpulkan bahwa digital marketing berdampak positif terhadap kinerja pemasaran dan pendapatan UMKM (Khairunnisa, 2020; Soejipto, 2020).

Berdasarkan kajian yang ditelaah melalui penelitian terdahulu dan teori para ahli, diharapkan model pengembangan yang dirancang oleh penulis dapat menjadi inovasi untuk membantu UMKM dalam mengejar ketertinggalan saat pandemi COVID-19.

\section{Kesimpulan}

Penggunaan digital marketing sangat berperan penting dalam pengembangan manajemen sumber daya manusia UMKM sector makanan dan minuman terutama pada era COVID-19. Pemanfaatan teknologi dan infromasi dapat menjadi media penyaluran informasi dan pemasaran produk secara luas. Dengan demikian, pada kondisi COVID-19 kegiatan pengembangan 
sumber daya manusia UMKM makanan dan minuman perlu ditingkatkan dengan pengadaan pelatihan secara online sebagai inovasi untuk bertahan pada keadaan pandemi COVID-19.Salah satunya adalah dengan pengembangan sumber daya manusia berbasis online atau teknologi dan infromasi dinilai dapat mendorong tumbuh dan berkembangnya UMKM di era teknologi informasi ini.Dalam penelitian ini, penggunaan model pengembangan manajemen sumber daya manusia UMKM sektor makanan dan minuman dapat bertumpu pada pemanfaatan teknologi dan informasi yang ditopang oleh dukungan pemerintah dan pihak UMKM dengan pelatihan-pelatihan online tentang IT terhadap pegawai UMKM akan mampu meningkatkan skill secara signifikan dan mengurangi tingkat rentan kebangkrutan UMKM di saat COVID-19. Selanjutnya, skill yang diterima variatif dan disesuaikan dengan kondisi pasar dan jenis makanan dan minuman yang djual ke pasar.

\section{Daftar Pustaka}

A. Alford, P., \& Page, S. J. (2015). Marketing technology for adoption by small business. Service Industries Journal, 35(11-12), 655-669.

https://doi.org/10.1080/02642069.2015.106 2884

B. Ananda, D.A. \& Susilowati D. (2018). Pengembangan Usaha Mikro Kecil dan Menengah (UMKM) Berbasis Industri Kreatif di Kota Malang. Jurnal Ilmu Ekonomi, 5,5,120-142.

C. Andayani, Indah; Roesminingsih, Maria Veronika; Yulianingsih, Wiwin. Strategi Pemberdayaan Masyarakat Pelaku UMKM Di Masa Pandemi Covid-19. Jurnal Pendidikan Nonformal, [S.1.], v. 16, n. 1, p. 12-20, mar. 2021. ISSN 2579-3950.

D. Angdika, N.A. \& Soeherman, B. (2019). Pemodelan Bisnis untuk Usaha Kecil Makro dan Menengah (UMKM) di Bidang Kuliner pada Era Revolusi Industri 4.0. Jurnal Sinegritas Multidisiplin Ilmu Pengetahuan dan Teknologi, 2, 26-27.

E. Anggraeni, F.D., Hardjanto, I., Hayat, A. (2013). Pengembangan Usaha Mikro, Kecil, dan Menengah (UMKM) Melalui Fasilitasi Pihak Eksternal dan Potensi Internal (Studi Kasus pada Kelompok Usaha Emping Jagung di Kelurahan Pandanwangi, Kecamatan Blimbing, Kota Malang). Jurnal Administrasi Publik, 1, 1, 1286-1295.
F. Bin Othayman, Majed \& Meshari, Abdulrahim \& Mulyata, John \& Debrah, Yaw. (2020). The Challenges Confronting the Delivery of Training and Development Programs in Saudi Arabia: A Critical Review of Research. American Journal of Industrial and Business Management. 10. 1611-1639. 10.4236/ajibm.2020.109103.

G. BPS, (2018). Berita Resmi Statistik. Badan Pusat Statistik, Jakarta - Indonesia.

H. Cahya. 2021. Analisis Pelatihan dan Pengembangan Sumber Daya Manusia. YUME: Journal of Management. Sekolah Tinggi Ilmu Ekonomi

I. Creswell, John W. (2017). Research Design Pendekatan Metode Kualitatif, Kuantitatif, dan Campuran (Edisi ke-4). Yogyakarta: Pustaka Pelajar.

J. Ekasari, N., \& Roza, S. (2018). Pelatihan Dasar-Dasar Manajemen Pada Usaha Mikro Kecil Menengah (UMKM) Keripik Pisang Dharma Jaya untuk Meningkatkan Kinerja Usaha. Jurnal Karya Abdi Masyarakat, 2(1), 31-36.https://doi.org/10.22437/jkam.v2i1.5 428

K. Eneh, S.I., Chukwuma, N.K., Gabriel, U. (2018). Salary Increase and Employee Productivity in Cement Manufacturing Companies in South-South Nigeria. IOSE Journal of Business and Management, 20, 01-08.

L. Fauji, Diah Ayu Septi dan Gesty Ernestivita. 2019. Analisis Karakteristik Pelaku UMKM (Usaha Mikro Kecil Menengah) di Kota Kediri. Prosiding Seminar Nasional dan Call for Papers. 125-132.

M. Febriyantoro, M. T., \& Arisandi, D. (2018). Pemanfaatan Digital Marketing Bagi Usaha Mikro, Kecil Dan Menengah Pada Era Masyarakat Ekonomi Asean. JMD: Jurnal Riset Manajemen \& Bisnis Dewantara, 1(2), 61-76.

https://doi.org/10.26533/jmd.v1i2.175

N. Gunawan, C.I. (2015). Strategi Manajemen Sumberdaya Manusia. CV. IRDH: Purworketo

O. Gunawan, C.I. (2016). Human Resources Management Based on Islam and Western View. CV. IRDH: Purwokerto

P. Gunawan, C.I. (2020). Lumbung Pangan Gratis Model Cakti Solusi Kelangkaan Pangan dan Chaos Dunia. CV. IRDH (Research and Publishing): Malang 
Q. Hakim, Lukmanul. (2019). Pelatihan Pemasaran Online Berbasis Marketplace Bagi UMKM Dalam Merespon Perubahan Perilaku Konsumen. 2. 74-91.

R. Hartono, Sony. Ubed, R.S. (2018). Pelatihan Online Marketing Kepada Pelaku UMKM Desa Cibogo, Cisauk, Tangerang. Seminar Hasil Pengabdian Masyarakat.

S. Hardilawati, W. L. (2019). Model Pemasaran Hubungan Pelanggan, Inovasi Dan E-Commerce Dalam Meningkatkan Kinerja Pemasaran UKM Di Pekanbaru. Jurnal Akuntansi Dan Ekonomika, 9(2), 213-222

T. Harel, R. (2021). The Impact of Covid-19 on Small Business's Performance and Innovation. International Journal Sage, 1, 01-22.

U. Hendriadi, Ade Andri \& Sari, Betha \& Nur Padilah, Tesa. (2019). Pelatihan Digital Marketing Usaha Mikro, Kecil dan Menengah (UMKM) di Kabupaten Karawang. J-Dinamika. 4 10.25047/j-dinamika.v4i2.1133.

V. Ibrahim, Amin (2003). Manajemen Sumber Daya Manusia. Rineka Cipta. Jakarta.

W. Khairunnisa, N., Lubis, D., Hasanah, Q (2020). Kenaikan Omzet UMKM Makanan dan Minuman di Kota Bogor Pasca Sertifikasi Halal. Jurnal Al-Muzara'ah, 8,2, 109-127.

X. Lazear, E.P. (2018). Compensation and Incentives in The Workplace. Journal of Economic Perspectives, 32, 3, 195-214.

Y. Ling, A. (2013). Pengelolaan dan Pengembangan Usaha Pada Usaha Mikro Kecil Menengah (Study Deskriptif pada Rumah Makan Palem Asri Surabaya). Jurnal Agora. 1. 1. $1-8$.

Z. Lubis, T.A., Junaidi. 2016. Pemanfaatan Teknologi Informasi pada Usaha Mikro Kecil dan Menengah di Kota Jambi. Vol. 3 No. 3. Fakultas Ekonomi dan Bisnis: Universitas Jambi

AA. Ludiya, H. (2017). Dampak dari Lingkungan Kerja dan Dukungan Organisasi Terhadap Motivasi Kerja Karyawan pada PT. Maruwa Batam. Jurnal Terapan Manajemen dan Bisnis, 3, 1, 21-41.

BB. Mandasari, J. D., Widodo, J., \& Djaja, S. (2019). Strategi Pemasaran Usaha Mikro, Kecil Dan Menengah (Umkm) Batik Magenda Tamanan Kabupaten Bondowoso. JURNAL PENDIDIKAN EKONOMI: Jurnal Ilmiah
Ilmu Pendidikan, Ilmu Ekonomi Dan Ilmu Sosial, $13(1), \quad 123$. https://doi.org/10.19184/jpe.v13i1.10432

CC. Marchand, A., Thurau, T.H., Flemming, J. (2021) Social Media Resources and Capabilities as Strategic Determinants of Social Media Performance. International Journal of Research in Marketing, 38, 549-571.

DD. Mashuri, M. (2019). Analisis Strategi Pemasaran UMKM Di Era 4.0. IQTISHADUNA: Jurnal Ilmiah Ekonomi Kita, 8(2), 215-224. https://doi.org/10.46367/iqtishaduna.v8i2.1 75

EE. Mukhsin. (2019). Manfaat Penerapan Marketing Online (Menggunakan E-Commerce Dan Media Sosial) Bagi Usaha Mikro, Kecil Dan Menengah (Umkm). Teknokom, 2(1), 1-10. https://doi.org/10.31943/teknokom.v2i1.25

FF. Rahman, M.R., Oktaviani, M. R., dkk. (2020). Perkembangan UMKM (Usaha Mikro Kecil dan Menengah) di Indonesia. Fakultas Ekonomi dan Bisnis Universitas Tanjungpura.

GG. Ratnawati. (2018). Tingkat Pendidikan, Pengetahuan Literasi Keuangan, Sustainability Usaha Sebagai Upaya Meningkatkan Kinerja Manajemen UKM. Jurnal Vidya, 24,2.1-9.

HH. Rifai, M., Indrihastuti, P., Sayekti, N. S., Gunawan, C.I. (2016). Strategy in Enhancing the Competitiveness of Small and Medium Enterprises in ASEAN Free Trade Era. International Journal of Academic Research in Business and Social Sciences: Vol. 6, No. 12. p 76-87. DOI: doi.org/10.6007/IJARBSS/v6-i12/247 1

II. Rodriguez, J., Walters, K. (2017). The Importance of Training and Development in Employee Performance and Evaluation. UGC : Approved Journal Impact (MJIF). World Wide Journal of Multidisciplilnary Research and Development.

JJ. Saunders, M. N. K., Gray, D. E., \& Goregaokar, H. (2014). SME innovation and learning: The role of networks and crisis events. European Journal of Training and Development. https://doi.org/10.1108/EJTD-07-2013-007 3

KK. Setyorini, D., Nurhayati, E., \& Rosmita. (2019). Pengaruh Transaksi Online (e-Commerce) Terhadap Peningkatan 
Laba UMKM (Studi Kasus UMKM

Pengolahan Besi Ciampea Bogor Jawa

Barat). Jurnal Mitra Manajemen,

3(5), 501-509

LL. Soemarno. (2004). Demokratisasi Teori Organisasi Menurut Perspektif

Postmodernisme, 2, 2, 220-229.

MM. Soetjipto, Noer (2020) Ketahanan UMKM Jawa Timur Melintasi Pandemi COVID-19.

NN. Sumampouw, W., Kurnia, K., Arrobi, I.R. (2021). Perlindungan Hukum Terhadap Usaha Mikro Kecil dan Menengah Pasca Berlakunya Undang-Undang Cipta Kerja. Jurnal de Jure, 13, 1, 24-39.

OO. Yuniarsih dan Suwatno. (2011). Manajemen Sumber Daya Manusia: Alfabeta. Bandung.

PP. Yuwinanto, Helmy. (2020). Pelatihan keterampilan dan upaya pengembangan UMKM di Jawa Timur. Jurnal Sosiologi Dialektika. 13.

79. 10.20473/dk.v13i1.2018.79-87. 